\title{
Distribution of Chemical Elements in Attic Dust as Reflection of Their Geogenic and Anthropogenic Sources in the Vicinity of the Copper Mine and Flotation Plant
}

\author{
Biljana Balabanova $\cdot$ Trajče Stafilov $\cdot$ \\ Robert Šajn · Katerina Bačeva
}

Received: 19 June 2010/Accepted: 30 August 2010/Published online: 22 September 2010

(C) Springer Science+Business Media, LLC 2010

\begin{abstract}
The main aim of this article was to assess the atmospheric pollution with heavy metals due to copper mining Bučim near Radovišs, the Republic of Macedonia. The open pit and mine waste and flotation tailings are continually exposed to open air, which leads to winds carrying the fine particles into the atmosphere. Samples of attic dust were examined as historical archives of mine emissions, with the aim of elucidating the pathways of pollution. Dust was collected from the attics of 29 houses, built between 1920 and 1970. Nineteen elements (Ag, Al, As, Ba, Ca, Cd, Co, Cr, Cu, Li, Fe, K, Mg, $\mathrm{Mn}, \mathrm{Na}, \mathrm{Ni}, \mathrm{Pb}, \mathrm{Sr}$, and $\mathrm{Zn}$ ) were analyzed by atomic emission spectrometry with inductively coupled plasma. The obtained values of the investigated elements in attic dust samples were statistically processed using nonparametric and parametric analysis. Factor analysis revealed three factors governing the source of individual chemical elements. Two of them grouping $\mathrm{Ca}, \mathrm{Li}, \mathrm{Mg}, \mathrm{Mn}$, and $\mathrm{Sr}$ (Factor 1) and $\mathrm{Co}, \mathrm{Cr}$, and $\mathrm{Ni}$ (Factor 2) can be characterized as geogenic. The third factor grouping $\mathrm{As}, \mathrm{Cu}$, and $\mathrm{Pb}$ is anthropogenic and mirrors dust fallout from mining operation and from flotation tailings. Maps of areal deposition were prepared for this group of elements, from which correlation of these anthropogenic born elements was confirmed.
\end{abstract}

B. Balabanova

Faculty of Agriculture, Goce Delčev University,

P.O. Box 201, 2000 Štip, Macedonia

T. Stafilov $(\bowtie) \cdot$ K. Bačeva

Institute of Chemistry, Faculty of Science, Sts. Cyril and

Methodius University, P.O. Box 162, 1000 Skopje, Macedonia

e-mail: trajcest@pmf.ukim.mk

R. Šajn

Geological Survey of Slovenia, Dimičeva ulica 14, 1000

Ljubljana, Slovenia
Atmospheric pollution with heavy metals is a global process, which is initiated by the world technology progress and human exploitation of natural resources (Athar and Vohora 1995; Järup 2003; West et al. 1997). Mining works have significant influences on this occurrence, because of the direct exposition of metal to the atmosphere. Mines produce large amounts of waste because the used ore and concentrates are only a small fraction of the total volume of the mined material (Dudka and Adriano 1997; Salomons 1995). Atmospheric emissions attributed to the extraction stage of mining come mainly from the action of wind on disturbed land and stockpiles of ore and waste material. As a result of these processes, dust is permanently introduced into the atmosphere (Repley et al. 1996; Sengupta 1993). Continuous monitoring of the content of heavy metals and other toxic components contained in dust is possible through implementation of monitoring by using samples of dust from attic beams (Ilacqua et al. 2003; Tye et al. 2006). Attic dust is derived primary from external sources through aerosol deposition and as a result of soil dusting, and less from household activities (Šajn 2003). Usefulness of attic dust as a suitable long-term monitor for the determination of the status and content of heavy metals in air is proven by numerous studies (Cyrys et al. 2003; Gosar et al. 2006; Jeffrey et al. 2005; Šajn 2005, 2006; Žibret 2008; Žibret and Šajn 2008a, b).

As a result of anthropogenetic activities, the Republic of Macedonia is affected by atmospheric pollution with heavy metals. Significant emission sources that contribute to atmospheric pollution with heavy metals for the territory of the Republic of Macedonia appear to be all mines and drainage systems and smelters near the cities of Veles, Kavadarci, and Tetovo (Barandovski et al. 2006, 2008; Stafilov et al. 2003, 2010a, b). In the eastern part of the 
Fig. 1 Studied area

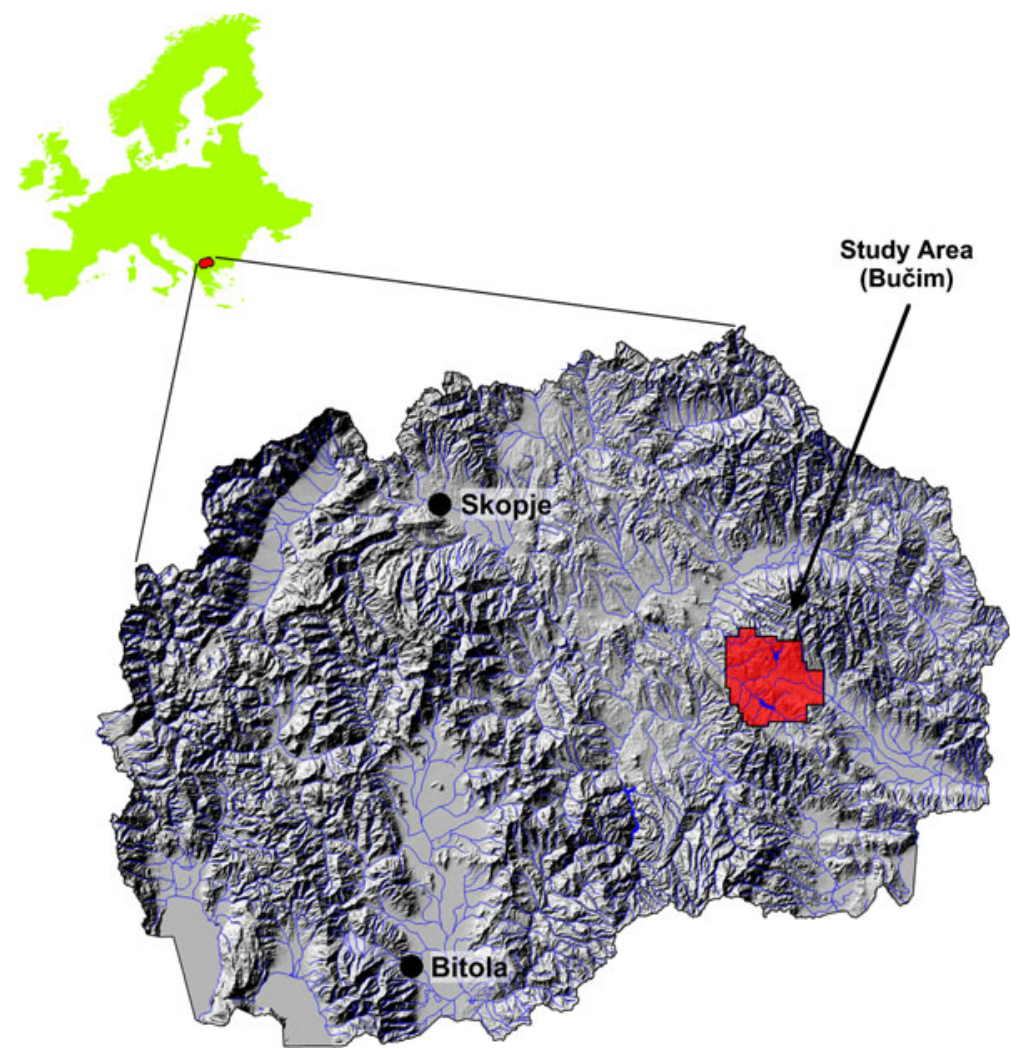

country, the occurrence of some metals (Au, Mg, Al, Sc, $\mathrm{Ti}, \mathrm{V}$, and $\mathrm{Cu}$ ) in air is related to a presence of a copper mine and flotation near Radoviš.

The Bučim copper mine, as the primary emission source of heavy metals in the area, is located in the central part of eastern Macedonia, near the city of Radoviš (Fig. 1). The mine has functioned since 1980 and processes 4 million tons of ore annually. The deposit is a porphyry copper-type deposit and mineralization is related to tertiary subvolcanic intrusions of andesite and latite in a host of Pre-Cambrian gneiss and amphibolite (Serafimovski et al. 1995). The main ore body is $\sim 500 \mathrm{~m}$ in diameter and $250 \mathrm{~m}$ deep and has been worked in a large open pit, which actually allows direct exposure of ore particles to the atmosphere. The ore contains the following: $0.3 \% \mathrm{Cu}, 0.3 \mathrm{~g} /$ ton $\mathrm{Au}, 1 \mathrm{~g} / \mathrm{ton} \mathrm{Ag}$, $13 \mathrm{~g} /$ ton Mo, and 1-4\% pyrite; the igneous rocks have been sericitized and argillitized. The important minerals are chalcopyrite, pyrite, and bornite, with small amounts of galena, sphalerite, magnetite, hematite, and cubanite (Alderton et al. 2005; Serafimovski et al. 2005). Ore is treated by flotation on site and flotation tailings are disposed at a dump site in an adjacent valley near Topolnica (Fig. 2). On the other hand, the ore wastes are disposed in the vicinity of an open pit (Fig. 2). Exposure of ore waste and flotation tailing to air and moisture leads to slow transformation of copper sulfide into copper oxide and sulfuric acid. This acid can dissolve heavy metals found in waste rock and tailings such as $\mathrm{Pb}, \mathrm{Zn}, \mathrm{As}, \mathrm{Se}, \mathrm{Hg}$, and $\mathrm{Cd}$
(Pandey et al. 2007). The fine particles from soil surface carried by the winds are introduced into the atmosphere (Kabata-Pendias and Pendias 2001).

The main object of this study was the assessment of atmospheric pollution with heavy metals due to copper mining activities near the mine using attic dust collected from houses in the investigated region. Nineteen elements (Ag, Al, As, Ba, Ca, Cd, Co, Cr, Cu, Li, Fe, K, Mg, Mn, $\mathrm{Na}, \mathrm{Ni}, \mathrm{Pb}, \mathrm{Sr}$, and $\mathrm{Zn}$ ) were analyzed by atomic emission spectrometry with inductively coupled plasma (ICP-AES).

\section{Study Area}

The study area is located in the eastern part of the Republic of Macedonia (Fig. 1), with an area of $20 \mathrm{~km} \mathrm{(W-}$ E) $\times 20 \mathrm{~km}(\mathrm{~S}-\mathrm{N})$ (total: $400 \mathrm{~km}^{2}$ ), which is limited within the coordinates $\mathrm{N}: 41^{\circ} 32^{\prime}-41^{\circ} 44^{\prime}$ and $\mathrm{E}$ : $22^{\circ} 15^{\prime}-$ $22^{\circ} 30^{\prime}$. The copper mine is located in the center of the study area, $10 \mathrm{~km}$ air line northwest from Radoviš and $16 \mathrm{~km}$ air line southeast from Štip. The region is characterized by a moderate continental climate. The average annual temperature is around $10^{\circ} \mathrm{C}$. The warmest months of the year are July and August, with an average temperature of $23^{\circ} \mathrm{C}$, and the coldest month is January, with an average temperature of $1.2^{\circ} \mathrm{C}$. The average annual rainfall amounts to $563 \mathrm{~mm}$, with large variations from year to year. In terms of the total annual number of sunny hours, for this 
Fig. 2 Sampling network and generalized geological map

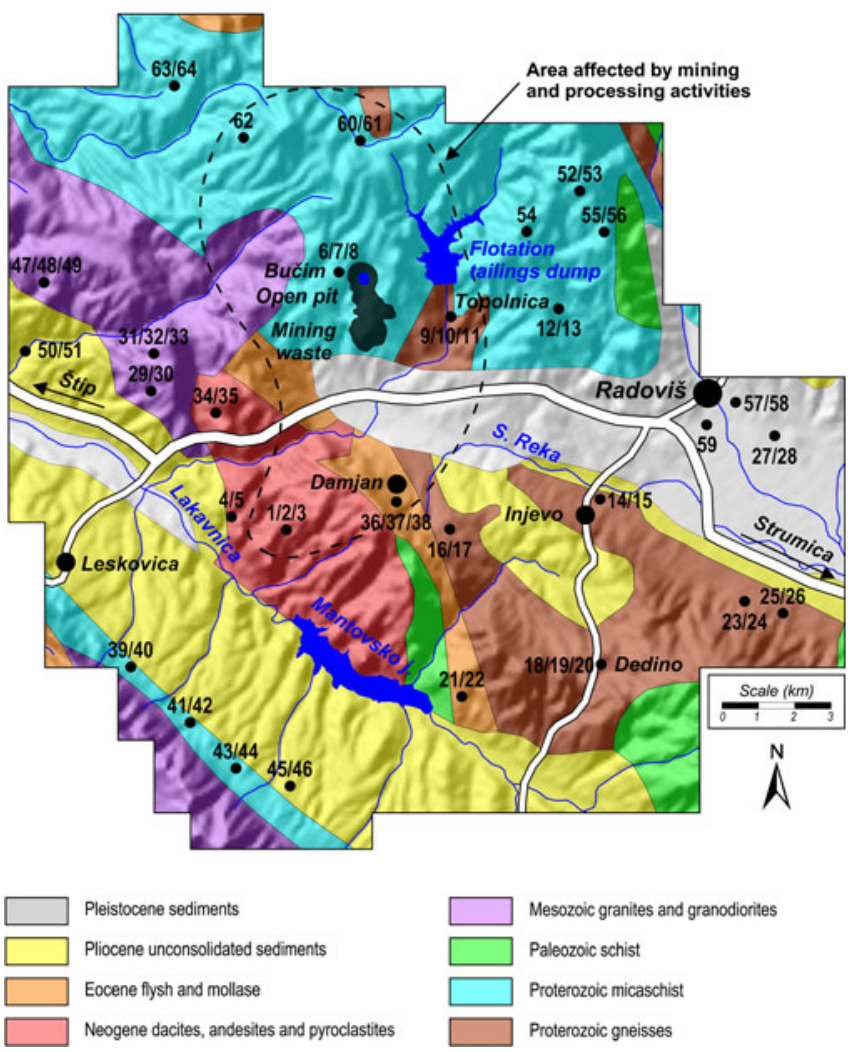

the attic timber was thrown away and the finest dust was collected. The fraction of attic dust smaller than $0.125 \mathrm{~mm}$ in size was prepared by sieving. In that form, samples of attic dust were ready for digestion.

\section{Sample Preparation}

For digestion of attic dust samples, open wet digestion with a mixture of acids was applied. Precisely measured mass of dust samples $(0.5 \mathrm{~g})$ was placed in Teflon vessels and $5 \mathrm{ml}$ concentrated nitric acid $\left(\mathrm{HNO}_{3}\right)$ was added until brown vapors came from the vessels. Nitric acid is a very suitable oxidant for digestion of environmental samples. For total digestion of inorganic components, 5-10 ml hydrofluoric acid was added. When the digest became a clear solution, $2 \mathrm{ml}$ of $\mathrm{HClO}_{4}$ was added. Perchloric acid was used for the total digestion of organic matter. After cooling the vessels for $15 \mathrm{~min}, 2 \mathrm{ml}$ of $\mathrm{HCl}$ and $5 \mathrm{ml}$ of $\mathrm{H}_{2} \mathrm{O}$ were added for total dissolving metal ions. Finally, the vessels were cooled and digests were quantitatively transferred to $50-\mathrm{ml}$ calibrated flasks.

\section{Reagents and Standards}

For this study, reagents of analytical grade (or better) were used: Nitric acid, trace pure (Merck, Germany), hydrofluoric acid, p.a. (Merck, Germany), perchloric acid, p.a. (Merck, Germany), hydrochloric acid, p.a. (Merck, 
Germany), and redistilled water was used for the preparation of all solutions. Standard solutions of metals were prepared by dilution of $1000-\mathrm{mg} / \mathrm{l}$ solutions (11355-ICP multi Element Standard).

\section{Instrumentation}

The following elements were determined: $\mathrm{Ag}, \mathrm{Al}, \mathrm{As}, \mathrm{Ba}$, $\mathrm{Ca}, \mathrm{Cd}, \mathrm{Co}, \mathrm{Cr}, \mathrm{Cu}, \mathrm{Li}, \mathrm{Fe}, \mathrm{K}, \mathrm{Mg}, \mathrm{Mn}, \mathrm{Na}, \mathrm{Ni}, \mathrm{Pb}, \mathrm{Sr}$, and $\mathrm{Zn}$. Analyses were performed with an atomic emission spectrometer with inductively coupled plasma (Varian, 715ES).

The quality control of ICP-AES determinations was performed by the standard addition method, and it was found that the recovery for the investigated elements ranged between 97.5 and $100.8 \%$. The same method was applied for the determination of some trace elements in the reference standard materials JSAC 0401 (soil) and SARM 3 (rock), yielding values very close to those certified.

\section{Data Processing}

For the statistical analysis of data, parametric and nonparametric statistic methods were used (Davis 1986; Hollander and Wolfe 1999). Percentiles, minimum and maximum, median, geometrical mean, and arithmetical mean were calculated and histograms were drawn to show the distribution features. Data distribution was examined with the application of a normality test. Analyzing of variance (ANOVA) was used for the determination of significant differences within selected populations. The application of bivariate statistics showed how chemical elements correlate between their content in attic dust samples. For that issue, the linear coefficient of correlation was used, and the absolute values $r>0.50$ indicate good association between variables. The multivariate statistic method was used to reveal the associations of the chemical elements. The factor analysis (FA) from an accurate number of variables provides smaller number of new variables, so-called factors that present the association of statistical significant variables (Davis 1986; Filzmoser et al. 2005; Reimann et al. 2002; Šajn 2006; Yongming et al. 2006; Žibret and Šajn 2010).

\section{Results}

The descriptive statistics of analyzed elements are shown in Table 1. Values of all elements are given in milligrams per kilogram. Normality tests were compared with histograms of distribution for the content of all analyzed elements in attic dust samples. The normality was assumed for

Table 1 Descriptive statistic of measurements for attic dust samples (given in $\mathrm{mg} / \mathrm{kg}$ )

\begin{tabular}{|c|c|c|c|c|c|c|c|c|c|c|c|c|c|}
\hline Element & $n$ & Dis. & $X_{\mathrm{a}}$ & $X_{\mathrm{g}}$ & $\mathrm{Md}$ & Min & Max & $\mathrm{P}_{10}$ & $\mathrm{P}_{90}$ & $\mathrm{~s}$ & $\mathrm{CV}$ & A & E \\
\hline $\mathrm{Ag}$ & 64 & $\log$ & 0.24 & 0.10 & 0.05 & 0.009 & 1.12 & 1.09 & 13.4 & 0.83 & 17.8 & 0.90 & -0.62 \\
\hline $\mathrm{Al}$ & 64 & $\mathrm{~N}$ & 11,040 & 10,292 & 10,886 & 1,787 & 21,957 & 6,407 & 16,085 & 3,797 & 34.4 & 0.26 & 0.39 \\
\hline As & 64 & $\log$ & 11.3 & 8.34 & 9.58 & 0.50 & 51.6 & 2.13 & 18.8 & 9.29 & 82.2 & -0.29 & -1.42 \\
\hline $\mathrm{Ba}$ & 64 & $\log$ & 4,635 & 361 & 146 & 3.95 & 38,676 & 24.2 & 21,121 & 10,533 & 227 & 0.43 & -0.83 \\
\hline $\mathrm{Ca}$ & 64 & $\mathrm{~N}$ & 6,049 & 4,681 & 5,950 & 342 & 18,833 & 1,380 & 10,609 & 3,624 & 59.9 & 0.79 & 1.30 \\
\hline $\mathrm{Cd}$ & 64 & $\log$ & 2.02 & 1.97 & 1.98 & 1.09 & 3.11 & 1.39 & 2.64 & 0.46 & 22.8 & -0.24 & -0.07 \\
\hline $\mathrm{Co}$ & 64 & $\log$ & 6.26 & 5.95 & 5.63 & 2.42 & 11.3 & 4.03 & 9.95 & 2.10 & 33.6 & 0.19 & 0.05 \\
\hline $\mathrm{Cr}$ & 64 & $\log$ & 38.7 & 34.8 & 31.1 & 16.7 & 110 & 23.8 & 78.1 & 21.3 & 55.2 & 1.19 & 0.80 \\
\hline $\mathrm{Cu}$ & 64 & $\log$ & 52.1 & 33.4 & 26.8 & 10.9 & 415 & 15.5 & 116 & 75.8 & 142 & 1.51 & 2.18 \\
\hline $\mathrm{Li}$ & 64 & $\log$ & 4.82 & 3.98 & 4.10 & 1.20 & 15.9 & 1.61 & 8.72 & 3.09 & 64.1 & -1.31 & 1.48 \\
\hline $\mathrm{Fe}$ & 64 & $\mathrm{~N}$ & 11,966 & 10,525 & 13,228 & 1,131 & 18,350 & 5,986 & 16,080 & 4,120 & 34.4 & 0.10 & -0.34 \\
\hline $\mathrm{K}$ & 64 & $\mathrm{~N}$ & 8,846 & 8,741 & 8,613 & 5,560 & 11,612 & 7,161 & 10,876 & 1,362 & 15.4 & 0.02 & -0.79 \\
\hline $\mathrm{Mg}$ & 64 & $\log$ & 1,321 & 642 & 715 & 24.6 & 5,859 & 94.3 & 3,414 & 1,399 & 106 & -0.43 & -0.66 \\
\hline $\mathrm{Mn}$ & 64 & $\log$ & 211 & 201 & 195 & 113 & 454 & 143 & 302 & 70.4 & 33.3 & 0.40 & -0.17 \\
\hline $\mathrm{Na}$ & 64 & $\log$ & 6,846 & 5,024 & 4,784 & 326 & 28,682 & 2,348 & 15,810 & 6,336 & 92.5 & -0.24 & 1.95 \\
\hline $\mathrm{Ni}$ & 64 & $\log$ & 23.1 & 20.2 & 17.2 & 8.94 & 58.7 & 11.5 & 41.4 & 12.5 & 54.3 & 0.43 & -1.11 \\
\hline $\mathrm{Pb}$ & 64 & $\log$ & 28.8 & 21.4 & 20.4 & 3.12 & 121 & 7.49 & 53.3 & 23.9 & 83.1 & -0.20 & -0.07 \\
\hline $\mathrm{Sr}$ & 64 & $\log$ & 36.1 & 28.4 & 32.1 & 3.64 & 141 & 10.3 & 60.9 & 25.2 & 69.8 & -0.74 & 0.92 \\
\hline $\mathrm{Zn}$ & 64 & $\log$ & 50.9 & 48.7 & 49.5 & 21.4 & 92.9 & 34.3 & 72.9 & 15.1 & 29.8 & -0.20 & 0.11 \\
\hline
\end{tabular}

Dis distribution ( $\log \log$-normal, $N$ normal); $n$ number of observation, $X_{\mathrm{a}}$ aritmetical mean, $X_{\mathrm{g}}$ geometrical mean, $M d$ median, $M i n$ minimum, Max maximum, $P_{10}=10$ percentile, $P_{90} 90$ percentile, $s$ standard deviation, $C V$ coefficient of variance, $A$ skewness, $E$ kurtosis 
natural values of $\mathrm{Al}, \mathrm{Ca}, \mathrm{Fe}$, and $\mathrm{K}$. For the rest of the elements, the normality was assumed on the basis of the logarithms of their contents.

Results from bivariate statistic are shown in the matrix of the correlation coefficient (Table 2). The correlation coefficient is a statistical parameter that describes the degree of similarity (linear dependence) between two random variables or sets of random variables. The content of every element was correlated to the content of the other elements separately, from which the values for the correlation coefficients $(r)$ were represented in the matrix. Because of the large number of variables (19 elements) a clear and generalized relation between the elements could not be singled out. The principal component analysis was applied for the grouping of separate statistically significant associations.

The universal method kriging with linear variogram interpolation was applied for the construction of the areal distribution maps of the factor scores (F1-F3) in attic dust samples (Figs. 3, 4, 5). The anthropogenic association of the elements $\mathrm{As}, \mathrm{Cd}, \mathrm{Cu}$, and $\mathrm{Pb}$ was the most significant area of interest. Distribution maps for these elements are shown in Figs. 6, 7, 8, 9. Seven classes of the following percentile values were selected: $0-10,10-25,25-40$, 40-60, 60-75, 75-90 and 90-100.

\section{Discussion}

Factor analysis was done based on the matrix of the correlation coefficients. Principal component factor analysis was used to identify and characterize associations of elements. From the 19 analyzed variables, seven elements ( $\mathrm{Ag}, \mathrm{Al}, \mathrm{Ba}, \mathrm{Fe}, \mathrm{K}, \mathrm{Na}$, and $\mathrm{Zn}$ ) had a low factor loading or tendency to form an independent factor and therefore do not belong to any factor group. However, these elements are generally naturally present in the environment, so they can be considered geogenic. The matrix of dominant rotated factor loadings is presented in Table 3. Three factors were identified-two geogenic and one anthropogenic-interpreted as Factor 1, Factor 2 and Factor 3, which include $67 \%$ of the variability of treated elements.

Factor $1(\mathrm{Ca}, \mathrm{Li}, \mathrm{Mg}, \mathrm{Mn}$, and $\mathrm{Sr})$

These elements are naturally found in soil as macroelements (Fig. 3). The contents of these elements are variable and are not related to any anthropogenic activities. Their sources are mainly natural phenomena such as rock weathering and chemical processes in soil. Occurrence of this factor is typical for the oldest formations in the
Republic of Macedonia (Proterozoic micaschist and Proterozoic gneisses).

Factor $2(\mathrm{Co}, \mathrm{Cr}, \mathrm{Ni})$

This factor presents a geogenic factor (Fig. 4). These determined elements are considered "natural" because their origin is primarily crustal-soil particles suspended and transported by wind. High factor loadings are related to some old formation such as Neogene dacites, andesites, and pyroclastites and Pliocene unconsolidated sediments.

Factor $3(\mathrm{As}, \mathrm{Cu}, \mathrm{Pb})$

Factor 3 associates chemical elements that indicate anthropogenic influence in the studied area (Fig. 5). This association of elements was expected because of the studied area's geology and the open pit mining and flotation activities. The acid drainage rapidly dissolved the elements, leading to increased content in soil. The open ore pit and flotation tailings dump allow direct exposure of the finest ore particles to the atmosphere. Corpuscle dust from the surface layer of the ore body and soil is spread in the atmosphere by the winds, thus performing atmospheric distribution of these elements in the vicinity of the mine. The high loading value for this factor was for $\mathrm{Cd}(0.47)$. That is because the higher content of this element is introduced to the environment as a result of anthropogenic activity. Urban elements and those related to mine activities in dust are associated with fine particles, which are preferentially mobilized by wind and trapped in attics (Miguel et al. 1999).

From the distribution map of Factor 3 scores and distribution maps for all elements from this factor (Figs. 6, 7, $8,9)$, it is clearly visible that the higher content of these elements is deposited in close vicinity to the mine (Fig. 5). Maps of areal element deposition from Factor 3 scores results from principal factor analysis (Fig. 5 and Table 3), which shows that attic dust samples with an increased content of $\mathrm{Cu}$ have an increased content for the rest of the elements from this factor; this confirms the influence of the present copper mine and flotation plant on the increase of the content of these metals in the atmosphere. In addition, chemical analyses of the ore concentrate and tailings were performed (Table 4) and the obtained results proving the previous conclusion; namely, it is obvious that the content of As $(860 \mathrm{mg} / \mathrm{kg}), \mathrm{Pb}(775 \mathrm{mg} / \mathrm{kg})$, and especially $\mathrm{Cu}$ (20.4\%) are significantly increased in $\mathrm{Cu}$ concentrate. It is also evident that the $\mathrm{Cu}$ content is high in flotation tailings $(614 \mathrm{mg} / \mathrm{kg})$.

The maximum values for the content of $\mathrm{As}, \mathrm{Cd}, \mathrm{Cu}$, and $\mathrm{Pb}$ are obtained from attic dust samples collected from old houses in Bučim (situated $1 \mathrm{~km}$ from the mine and $2.5 \mathrm{~km}$ 


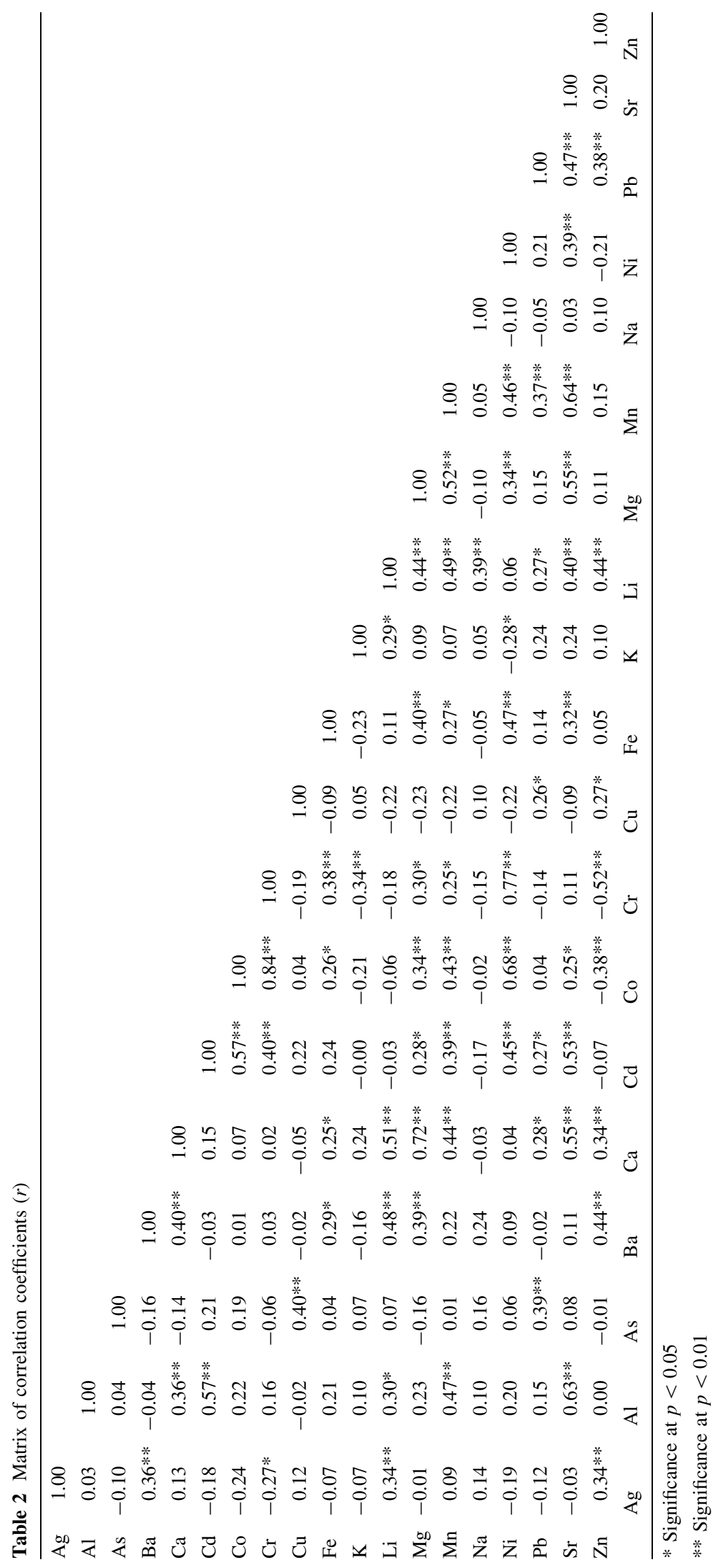


Fig. 3 Spatial distribution of Factor 1 scores $(\mathrm{Ca}, \mathrm{Li}, \mathrm{Mg}$, $\mathrm{Mn}, \mathrm{Sr}$ ) in attic dust samples

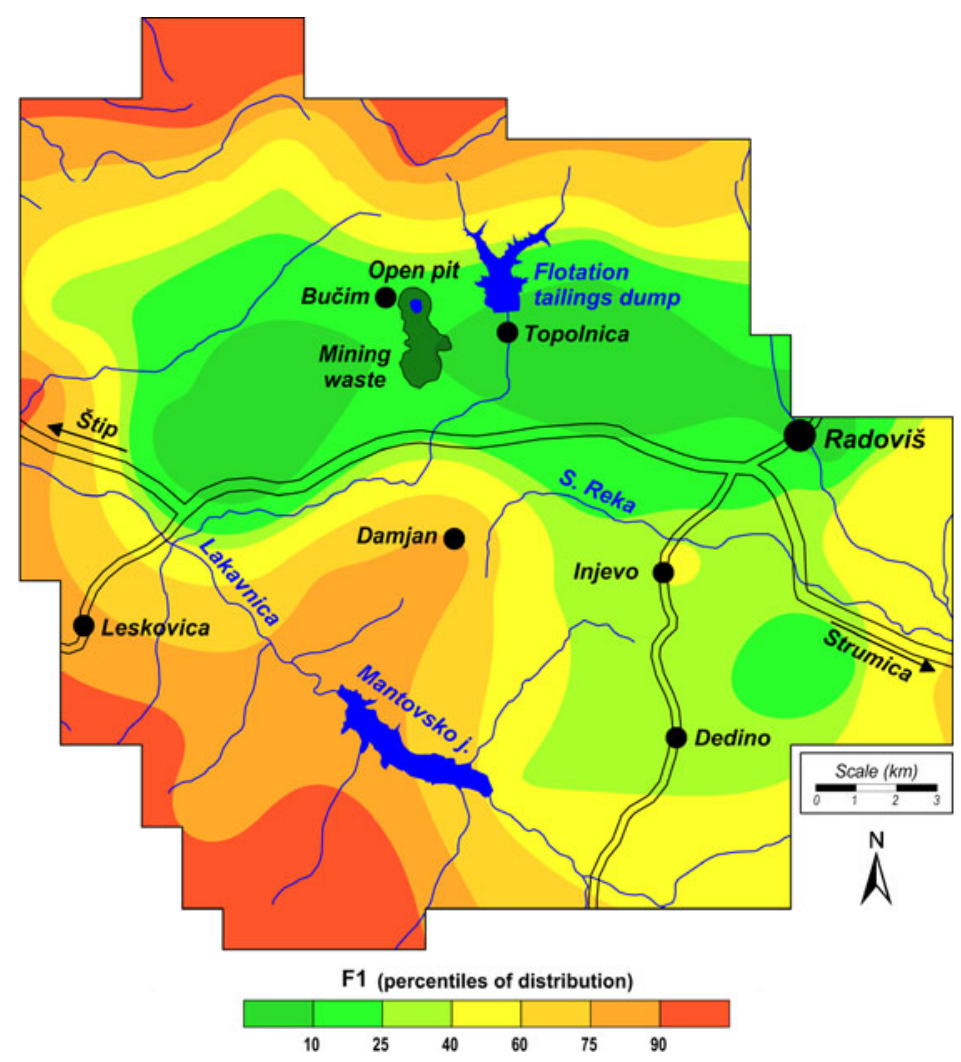

Fig. 4 Spatial distribution of Factor 2 scores $(\mathrm{Co}, \mathrm{Cr}, \mathrm{Ni})$ in attic dust samples
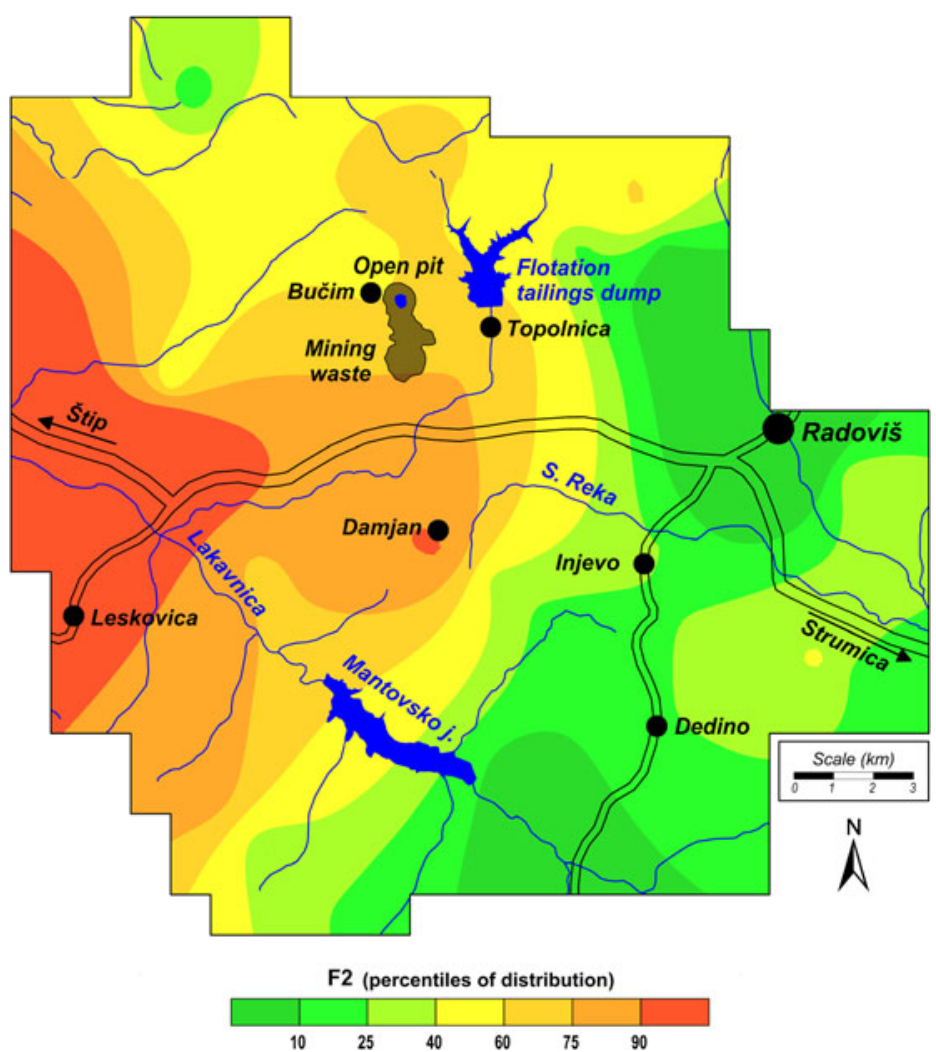

from the flotation tailings dump) and Topolnica (situated $1 \mathrm{~km}$ from the flotation tailings dump and $2.5 \mathrm{~km}$ from the mine site (Figs. 2, 5). The median values for the content of these elements in samples taken from the houses of the settlements in close mine vicinity separated from other samples from a distant area of the mine (Table 4) are as 
Fig. 5 Spatial distribution of

Factor 3 scores (As, $\mathrm{Cd}, \mathrm{Cu}, \mathrm{Pb}$ )

in attic dust samples

Fig. 6 Spatial distribution of As
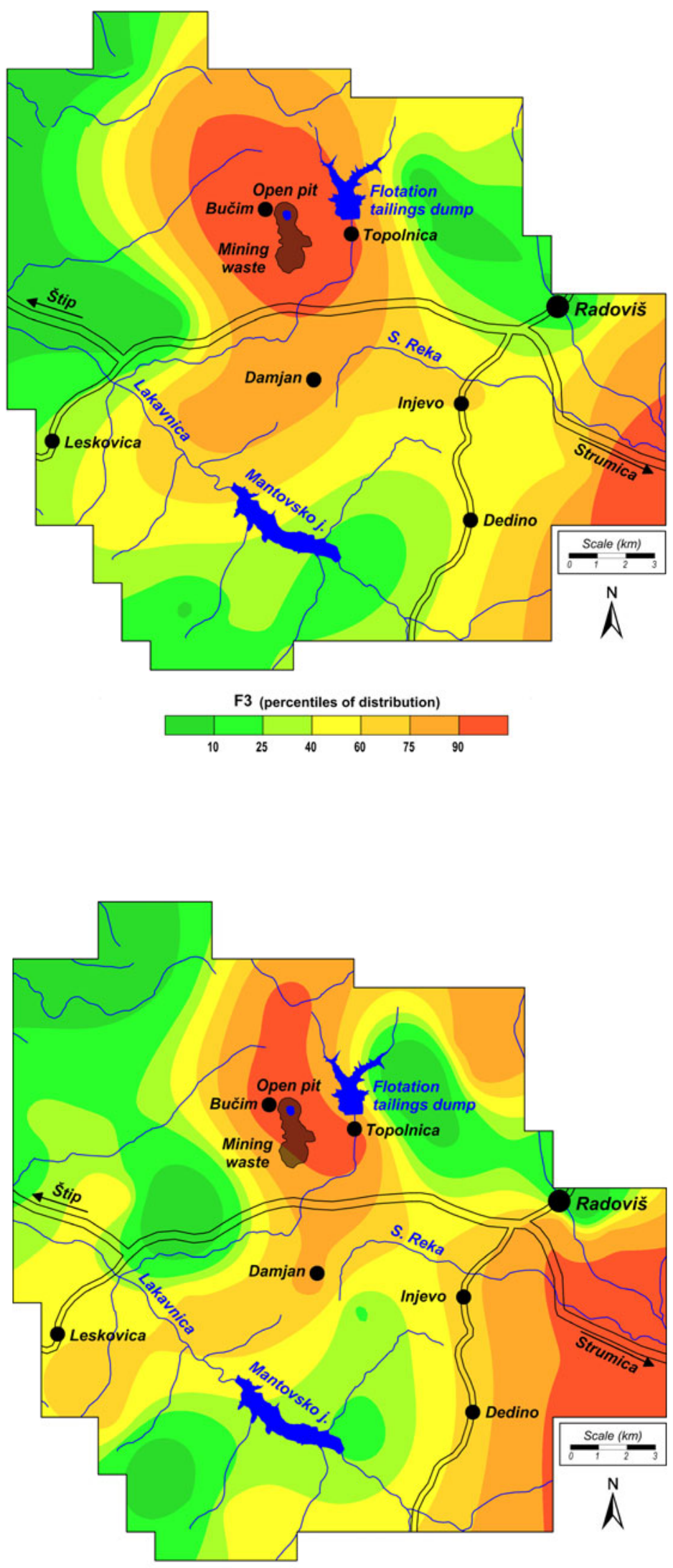

As $(\mathrm{mg} / \mathrm{kg})$

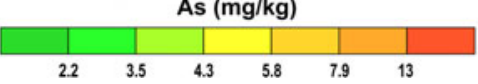


Fig. 7 Spatial distribution of $\mathrm{Cd}$

Fig. 8 Spatial distribution of $\mathrm{Cu}$
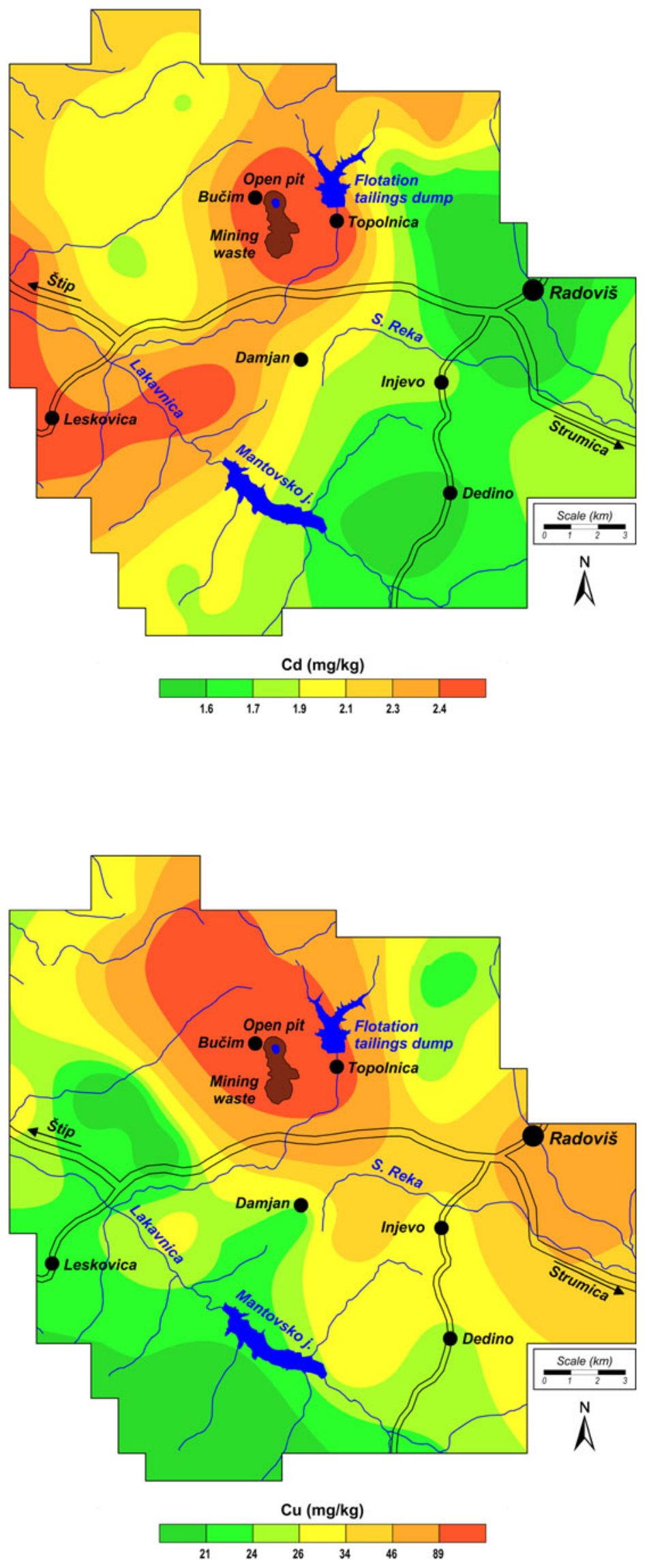
Fig. 9 Spatial distribution of $\mathrm{Pb}$

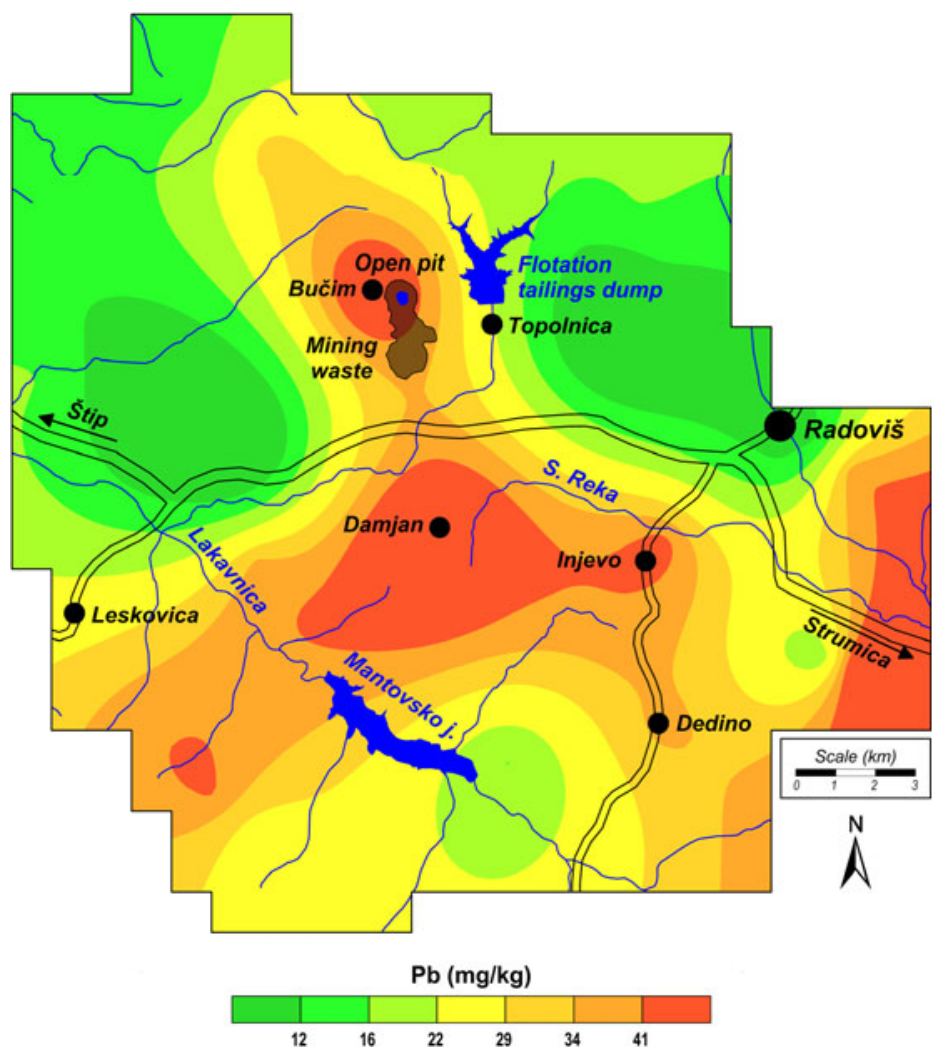

Table 3 Matrix of dominant rotated factor loadings $(F>0.60)$

\begin{tabular}{lrrrr}
\hline & \multicolumn{1}{c}{ F1 } & \multicolumn{1}{l}{ F2 } & \multicolumn{1}{c}{ F3 } & Com \\
\hline $\mathrm{As}$ & -0.08 & -0.06 & $\mathbf{0 . 7 8}$ & 62 \\
$\mathrm{Ca}$ & $\mathbf{0 . 8 0}$ & -0.03 & -0.09 & 70 \\
$\mathrm{Cd}$ & 0.27 & $\underline{0.51}$ & $\underline{0.47}$ & 67 \\
$\mathrm{Co}$ & 0.04 & $\mathbf{0 . 8 9}$ & 0.09 & 89 \\
$\mathrm{Cr}$ & -0.07 & $\mathbf{0 . 9 0}$ & -0.23 & 89 \\
$\mathrm{Cu}$ & -0.18 & -0.07 & $\mathbf{0 . 7 0}$ & 57 \\
$\mathrm{Li}$ & $\mathbf{0 . 8 1}$ & -0.18 & 0.04 & 80 \\
$\mathrm{Mg}$ & $\mathbf{0 . 7 8}$ & 0.21 & -0.22 & 79 \\
$\mathrm{Mn}$ & $\mathbf{0 . 7 6}$ & 0.34 & 0.11 & 80 \\
$\mathrm{Ni}$ & 0.19 & $\mathbf{0 . 8 5}$ & 0.04 & 65 \\
$\mathrm{~Pb}$ & 0.27 & 0.09 & $\mathbf{0 . 7 0}$ & 81 \\
$\mathrm{Sr}$ & $\mathbf{0 . 7 2}$ & 0.11 & 0.19 & 66 \\
$\mathrm{Var}$ & $\mathbf{3 1}$ & $\mathbf{1 9}$ & $\mathbf{1 6}$ & $\mathbf{6 7}$ \\
\hline
\end{tabular}

F1, F2, F3 factor loading, Var variance (\%), Com communality (\%) Numbers in bold correspond to the dominant rotated factor loadings with a value over 0.60

follows: $14 \mathrm{mg} / \mathrm{kg}$ for As; $2.6 \mathrm{mg} / \mathrm{kg}$ for $\mathrm{Cd} ; 110 \mathrm{mg} / \mathrm{kg}$ for $\mathrm{Cu}$, and $37 \mathrm{mg} / \mathrm{kg}$ for $\mathrm{Pb}$ compared with those for whole investigated area, which are $3.9 \mathrm{mg} / \mathrm{kg}, 1.9 \mathrm{mg} / \mathrm{kg}$, $26 \mathrm{mg} / \mathrm{kg}$, and $17 \mathrm{mg} / \mathrm{kg}$ for $\mathrm{As}, \mathrm{Cd}, \mathrm{Cu}$, and $\mathrm{Pb}$, respectively.
Table 4 Average contents of investigated chemical elements in flotation tailings and $\mathrm{Cu}$ concentrate

\begin{tabular}{lll}
\hline Element & Flotation tailings & $\mathrm{Cu}$ concentrate \\
\hline In percent & & \\
$\mathrm{Al}$ & 1.25 & 0.48 \\
$\mathrm{Ca}$ & 0.44 & 0.67 \\
$\mathrm{Fe}$ & 1.90 & 23.22 \\
$\mathrm{~K}$ & 2.40 & 0.11 \\
$\mathrm{Na}$ & 1.74 & 0.54 \\
$\mathrm{Mg}$ & 0.54 & 0.50 \\
$\mathrm{In} \mathrm{mg/kg}$ & & \\
$\mathrm{Ag}$ & $<1$ & 19.2 \\
$\mathrm{As}$ & 31.4 & 860 \\
$\mathrm{Ba}$ & 234 & 66.9 \\
$\mathrm{Cd}$ & 0.10 & 36.8 \\
$\mathrm{Co}$ & 8.55 & 67.0 \\
$\mathrm{Cr}$ & 32.8 & 6.1 \\
$\mathrm{Cu}$ & 614 & 204,176 \\
$\mathrm{Mn}$ & 177 & 975 \\
$\mathrm{Ni}$ & 10.4 & 54.9 \\
$\mathrm{~Pb}$ & 20.1 & 775 \\
$\mathrm{Sr}$ & 46.2 & 12.0 \\
$\mathrm{Zn}$ & 26.4 & 959 \\
\hline & &
\end{tabular}


Table 5 Descriptive statistic, ER, and ANOVA test regarding to surveyed areas

\begin{tabular}{|c|c|c|c|c|c|c|c|c|c|c|}
\hline & \multicolumn{4}{|c|}{ Affected area $(n=15)$} & \multicolumn{4}{|c|}{ Rest of studying area $(n=49)$} & \multirow[t]{2}{*}{ ER } & \multirow[t]{2}{*}{$F$} \\
\hline & $X_{\mathrm{g}}$ & Md & Min & Max & $X_{\mathrm{g}}$ & $\mathrm{Md}$ & Min & $\operatorname{Max}$ & & \\
\hline As & 10.4 & 14.2 & 1.29 & 32.7 & 2.62 & 3.89 & 0.50 & 51.6 & 3.66 & $11.8^{*}$ \\
\hline $\mathrm{Cd}$ & 2.43 & 2.6 & 1.73 & 3.09 & 1.85 & 1.87 & 1.09 & 3.11 & 1.36 & $21.0 *$ \\
\hline $\mathrm{Cu}$ & 74.0 & 110 & 14.4 & 415 & 26.2 & 26.0 & 10.9 & 68.8 & 4.23 & $28.1 *$ \\
\hline $\mathrm{Pb}$ & 36.0 & 37.4 & 10.3 & 104 & 18.2 & 17.0 & 3.12 & 121 & 2.20 & $9.39 *$ \\
\hline
\end{tabular}

$n$ number of observation, $X_{\mathrm{g}}$ geometrical mean, $M d$ median, min minimum, max maximum, $E R$ affected area/rest of area enrichment ratios (Md), $F$ continuous probability distribution (ANOVA)

* Significance at $p<0.05$

The enrichment ratio for $\mathrm{As}, \mathrm{Cd}$, and $\mathrm{Pb}$ is between 1.4 and 3.7 times, but the highest enrichment ratio is found for $\mathrm{Cu}$ (4.2) (Table 5). A significant difference of population is additionally verified with the ANOVA test. This is because of the presence of the mine and mining $\mathrm{Cu}$ minerals, which result in the introduction of a higher $\mathrm{Cu}$ content in the environment.

\section{Conclusion}

The activities carried out in the copper mine and flotation lead to increased content of certain heavy metals in the atmosphere, which was determined through the monitoring of attic dust samples. The enforcement of statistical factor analysis singled out one anthropogenic group of elements $(\mathrm{As}, \mathrm{Cd}, \mathrm{Cu}$, and $\mathrm{Pb})$. The fine particles from the mining operation are spread in the atmosphere carried by wind. Microparticles penetrate the human body through inhalation via the respiratory system. The second potential emission source of heavy metals is flotation tailings, which is a dominant pollutant to the soil. The acid drainage system dissolves heavy metals present in the soil such as those contained naturally in soil minerals and concentrates of it. From here, the fine particles from the soil surface are taken back into the atmosphere.

The highest values for $\mathrm{As}, \mathrm{Cd}, \mathrm{Cu}$, and $\mathrm{Pb}$ were obtained from attic dust samples from Bučim and Topolnica houses $(52 \mathrm{mg} / \mathrm{kg}$ for As; $3.1 \mathrm{mg} / \mathrm{kg}$ for $\mathrm{Cd} ; 415 \mathrm{mg} / \mathrm{kg}$ for $\mathrm{Cu}$, and $121 \mathrm{mg} / \mathrm{kg}$ for $\mathrm{Pb}$ ). Median values for the investigated elements did not indicate a significant anthropogenic effect on the environment. However, the values obtained for the content of $\mathrm{As}, \mathrm{Cd}$, and $\mathrm{Pb}$ in attic dust samples from the nearest mine settlements show values 1.4-3.7 times higher compared with the corresponding medians; for $\mathrm{Cu}$, it is 4.2 times higher.

Maps of areal deposition of heavy metals in the area around the Bučim mine show that these metals have an increased content in close vicinity of the mine. The high content of $\mathrm{Cu}$ in attic dust was collected in close vicinity of the mine. The population from Bučim and Topolnica is directly exposed to the presence of these heavy metals in the atmosphere, which is certainly worrisome from the aspect of human health risk.

\section{References}

Alderton DHM, Serafimovski T, Mullen B, Fairall K, James S (2005) The chemistry of waters associated with metal mining in Macedonia. Mine Water Environ 24:139-149

Athar M, Vohora S (1995) Heavy metals and environment. New Age International Publishers, New Delhi

Barandovski L, Cekova M, Frontasyeva MV, Pavlov SS, Stafilov T, Steinnes E, Urumov V (2006) Air pollution studies in Macedonia using the moss biomonitoring technique, NAA, AAS and GIS Technology. Preprint E18-2006-160. Joint Institute for Nuclear Research, Dubna

Barandovski L, Cekova M, Frontasyeva MV, Pavlov SS, Stafilov T, Steinnes E, Urumov V (2008) Atmospheric deposition of trace element pollutants in Macedonia studied by the moss biomonitoring technique. Environ Monitor Assess 138:107-118

Cyrys J, Stölzel M, Heinrich J, Kreyling WG, Menzel N, Wittmaack K, Tuch T, Wichmann HE (2003) Elemental composition and sources of fine and ultrafine ambient particles in Erfurt, Germany. Sci Total Environ 305:143-156

Davis JC (1986) Statistic and data analysis in geology. Wiley, New York

Dudka S, Adriano CD (1997) Environmental impacts of metal ore mining and processing: a review. J Environ Qual 26:590-602

Filzmoser P, Garrett RG, Reimann C (2005) Multivariate outlier detection in exploration geochemistry. Comput Geosci 31:579-587

Gosar M, Šajn R, Harald B (2006) Binding of mercury in soils and attic dust in the Idrija mercury mine area (Slovenia). Sci Total Environ 369:150-162

Hollander M, Wolfe DA (1999) Nonparametric statistical methods, 2nd edn. Wiley, New York

Ilacqua V, Freeman NC, Fagliano JP, Lioy J (2003) The historical record of air pollution as defined by attic dust. Atmos Environ 37:2379-2389

Järup L (2003) Hazards of heavy metal contamination. Br Med Bull $68: 167-182$

Jeffrey J, Davisa B, Gulson BL (2005) Ceiling (attic) dust: a "museum" of contamination and potential hazard. Environ Res 99:177-194

Kabata-Pendias A, Pendias H (2001) Trace elements in soil and plants, 3rd edn. CRC Press, Boca Raton 
Miguel E, Llamas JF, Chacon E, Mazadiego LF (1999) Sources and pathways of trace elements in urban environments: a multielemental qualitative approach. Atmos Environ 31:2733-2740

Pandey PK, Sharma R, Pandey M (2007) Toxic mine drainage from Asia's biggest copper mine at Malanjkhand, India. Environ Geochem Health 29:237-248

Rakićević T, Dumurdzanov N, Petkovski M (1968) Basic geological map of SFRJ, sheet Štip, M 1:100, 000 (map \& interpreter). Federal Geological Survey, Beograd

Reimann C, Filzmoser P, Garrett RG (2002) Factor analysis applied to regional geochemical data: problems and possibilities. Appl Geochem 17:185-206

Repley EA, Redmann RE, Crowder AA (1996) Environmental effects of mining. St. Lucie Press, Delray Beach

SFRJ (1965) Basic geological map of SFRJ, sheet Štip, M 1:100, 000. Federal Geological Survey, Beograd

Šajn R (2003) Distribution of chemical elements in attic dust and soil as reflection of lithology and anthropogenic influence in Slovenia. J Phys 107:1173-1176

Šajn R (2005) Using attic dust and soil for the separation of anthropogenic and geogenic elemental distributions in an old metallurgic area (Celje, Slovenia). Geochemistry 5:59-67

Šajn R (2006) Factor analysis of soil and attic-dust to separate mining and metallurgy influence, Meza valley, Slovenia. Math Geol 38:735-746

Salomons W (1995) Environmental impact of metals derived from mining activities: processes, predictions, preventions. J Geochem Explor 44:5-23

Sengupta M (1993) Environmental impacts of mining: monitoring, restoration and control. Lewis Publishers, Boca Raton, pp 4-10

Serafimovski T, Jankovic S, Cifliganec V (1995) Alpine metallogeny and plate tectonics in the SW flank of the Carpatho-Balkanides. Geol Macedonia 9:3-14

Serafimovski T, Alderton DHM, Dolenec T, Tasev G, Dolenec M (2005) Metal pollution around the Bučim Mine. In: Third international workshop on the UNESCO-IGCP project: anthropogenic effects on the human environment in tertiary basins in the Mediterranean, Štip

Stafilov T, Bojkovska R, Hirao M (2003) Air pollution monitoring system in the Republic of Macedonia. J Environ Protect Ecol $4: 518-524$

Stafilov T, Šajn R, Pančevski P, Boev B, Frontasyeva MV, Strelkova LP (2010a) Heavy metal contamination of surface soils around a lead and zinc smelter in the Republic of Macedonia. J Hazard Mater 175:896-914

Stafilov T, Šajn R, Boev B, Cvetković J, Mukaetov D, Andreevski M, Lepitkova S (2010b) Distribution of some elements in surface soil over the Kavadarci Region, Republic of Macedonia, Environ Earth Sci. doi:10.1007/s12665-010-0467-9

Tye AM, Hodgkinson ES, Rawlins BG (2006) Microscopic and chemical studies of metal particulates in tree bark and attic dust: evidence for historical atmospheric smelter emissions, Humberside, UK. J Environ Monit 8:904-912

West S, Charman DJ, Grattan JP, Cherburkin AK (1997) Heavy metals in holocene peats from south west England: detecting mining impacts and atmospheric pollution. Water Air Soil Pollut 100:343-353

Yongming H, Peixuan D, Junji C, Posmentier ES (2006) Multivariate analysis of heavy metal contamination in urban dusts of Xi' an, Central China. Sci Total Environ 355:176-186

Žibret G (2008) Determination of historical emission of heavy metals into the atmosphere: Celje case study. Environ Geol 56:189-196

Žibret G, Šajn R (2008a) Impacts of the mining and smelting activities to the environment-Slovenian case studies. In: Sanchez ML (ed) Causes and effects of heavy metal pollution. Nova Science Publishers, New York, pp 1-80

Žibret G, Šajn R (2008b) Modeling of atmospheric dispersion of heavy metals in the Celje area, Slovenia. J Geochem Explor 97(1):29-41

Žibret G, Šajn R (2010) Hunting for geochemical associations of elements: factor analysis and self-organising maps. Math Geosci 42:681-703 